\title{
INSOLVENCY [Poetry/ Fiction]
}

\author{
Angela Brown \\ E-mail: brownlas6@aol.com
}

Doi:10.7575/aiac.alls.v.5n.5p.10

Received: 13/06/2014

URL: http://dx.doi.org/10.7575/aiac.alls.v.5n.5p.10

Accepted: 11/08/2014

\begin{abstract}
It has been created within the larger realm culture, in that "Black methodology differs from most colonial differences by members of a minority community who reside within a nation of cultural biases."
\end{abstract}

Keywords: Black Scholar, Black Methodology, Blackness Theory

\section{Introduction}

Brown poems are inspired by her aesthetic beauty keying messages of liberty, desponding meaning through dance, expelling reason through sound, desponding language through hymns as she uplifts her audience through an American epic reflective of the social conditions of American culture.

\section{Expansion}

Voices echoing, muttering sounds

Like a black hawk calling its mate.

Crying out, searching, crying out,

No response.

Pain will pierce the heart,

Sorrow will be a hallow shell,

Memories will be broken,

Words of the mentally ill.

Difficulty is the prisoner of self-thought,

Voices die within a glass shield.

Words have become a vacant lot,

Racy thoughts ready to explode.

Words pulled from my lips

Recognizes forbidden truth

Dangling in the spoken absence of confusion.

A delusional mind wonders across the page

Infinitely desponding madness.

\section{Indulgence}

Voices climb effortlessly through this gate of thorns

I become another wasted suicide.

I become prisoner to stolen voices

empty hearts letting go

Relationships pierce the glass ceiling of my heart $i$ cry for all the life I love. 
I become the disabled poet singing words into a barren sky

Voices sing my name backwards lead me into a dance of death.

Invisible wings

cover my fears

Invisible wings

cover my scars.

I pray for a river of love where my feet dance joy

I cry for a river of love where my soul flows.

I am the old poet

of pain regret burden

I am the new poet

writing life back into my breath.

\section{Love Burns}

You failed to understand

True love is a bind

I will love you when you're down

I will hold true for eternity

For our love holds no boundary

Keeping our fate until serenity

Joyful tears of regret

If I could take it all away

Our love is true

Love is about you

Love is what burns

Within my heart

You carry my soul

Our fate for serenity

When you left me alone

I felt empty inside

Love full blown

Love denied

Our love burns

It burns, it burns, it burns...

For what I hoped was true

Our feelings were bare

Love is how I feel

For all I know is real

Someday

Love burns 
The lesson lovers learn

Real love burns

Love burns inside...oh it burns, it burns, and it burns

Of what my heart reveals

The importance of youth

Of what our heart conceals

Let it burn, let it burn, let true love burn

\section{Rain}

Chorus:

Rain, rain falling

Rain falling down

Let it rain

Let it rain

Let it rain

Trying to find a piece of mind

The meaning to love

Been meaning to explain

The way I'm feeling

Deep my emotions

The words I been meaning to say

Love, and it ends in silence...

With this feeling

I cannot keep running away

Chorus

I got it bad

I, alone and confused

Knowing there aren't no love

Like the love I am feeling now

Silence is so cold

Let it rain, rain, rain down, down down

With you I cannot live without

The pain that passes

Wondering if it's worth while

The possibility of hope

Dwindling through time

Right now my choice is to be with you

I am nothing without you

You are the motions, fantasies, desire 
The erupts passion inside

This feeling is the meaning

Why love happens to

\section{Chorus}

Let it rain, rain

Let it pour rain, rain

Rain

Rain

I feel you feel it too

The meaning of love...just happens

Waiting for you to respond...

To the rain?

\section{All of Me}

Chorus:

You are all of me

I am all of you

Kept inside

For so long

Memories of you

Crazy love, crazy love

I be all night thinking of you

Crazy love, crazy love

My memories of you

Memories, my memories

Crazy love

For too long baby

I been tempering your looks

I been craven your touch

I been talking to myself

You've been gone for too long

Crazy love, wanting you, feeling you

I'm missing you, crazy love

\section{Chorus}

Crazy love, crazy love

I be all night thinking of you

Crazy love, crazy love

My memories of you

Memories, my memories

Crazy love 
I cannot believe this happened to us

When you were all I got

Without you, babe, in my life

All my dreams, I am not the same

I get on my knees, praying for your return

My life is not complete without you apart of my dreams

My memories of you, my first true love

I cannot stop thinking of you, my friend

The memories are so real,

Your sensitive touch

Your sincere embrace

Into tears of affection

The memories we shared

Chorus

Crazy love, crazy love

I be all night thinking of you

Crazy love, crazy love

My memories of you

Memories, my memories

Crazy love

\section{Broken Love}

Chorus:

I believe in miracles

I believe in dreams

I believe I have a voice to be heard

I believe I can fly

I believe

I believe

I believe in celestial stars

Dancing in heaven above

I believe in rain falling from the sky

Is a sign of love, a sign of love?

I believe

Chorus

I believe in family

Present the times in need

I believe friends who support me

I believe in you and me 
Chorus

I believe in the Lord

Is there when I call

Delivering me with just cause

To surrender love

And when I'm in doubt

I feel the pain, is a special healing

A prayer of hope that delivers

I pray and he answers my calls

He is a caring God

Never in doubt, am I not alone

\section{Chorus}

Not knowing what is promised tomorrow

I believe in miracles of life

He promised me he would deliver

And it's enough for me

To believe...

Sorry, I never took the time

Sorry, I never said well by

Sorry, I never made the time

Broken love

Sorry I was not there when you needed me

Sorry, I never tried to understand

Wishing the pain away

Sorry for the times I failed to speak

What was on my mind?

I found an excuse, excuses turn

Into tears, falling, wishing, thinking

Sorry for the times I missed

The pain burns

Sorry, I never took the time

Sorry, I never said well by

Sorry, I never made the time

Broken love

What words, emotions say...Sorry

Tears falling, falling, falling down

Broken love

I abandoned you

With humility of being alone 
Shattering the trust we had

The love within our hearts...searching time

In fear of passion

In fear of pain

Abandoning love

Sorry, I never took the time

Sorry, I never said well by

Sorry, I never made the time

Broken love

My Grandmother, by Angela Brown

$\mathrm{Na} \mathrm{Na}$ 's journey was a long walk

From many cracked walls of opened eyes

With a bond that kept her family together

Because she always cared.

No Na kept scores of memories

Behind the lessons taught

She planted the seeds that nurtured dreams

Her family was a blessing to her

Of many generations pleaded to be free.

Never had she walked alone

Never did she regret her own

A child fallen in love or fallen astray

Through the dark, heavy night.

Her weight was the source of connection

That breathed life with family tradition

Through her scared and battered hands

That built the walls behind the pain.

$\mathrm{Na}$ Na's lips, empty of emotion

Unspoken words, hidden pride

Not knowing what would become of her children

She instilled the ability, her children, to learn.

She never taught me how to hate

To feel the weight at my waist

And to shy away the narrowed truth of the sun

But to melt away tempted desire

Finding hope and faith to love.

Like patience comes with virtue

Solace comes from pain

$\mathrm{Na} \mathrm{Na}$ fed me many words of wisdom

A guided source to reign.

\section{I am Woman}

I am a wide bowl

With a warm, wet opening 
Waiting for the storm to rain

Inside of my love channel

Asking her man for a refill

I am the empty jar

Whose hips are wide and vein

Asking to be held, grasped and cradled

Already demanding attention from her man

I am the plastic bottle

Whose small lips ask

To be pulled, squeezed, stretched and molded

Into a firm round melon

Yearning to be cupped by her man

I am a book

Whose source ask to be

Scanned, read and analyzed for comprehension

Because she likes to be noticed by her man

I am a woman

Not your bitch, yo ho, yo thing

I have moral values to withhold a relationship

And I ask to be needed, trusted and loved

I demand respect in a relationship

From the man she chose

I am a bowl, waiting to be drenched

I am a jar, waiting to be held

I am a bottle, waiting to be touched

I am a book, waiting to be opened

I am woman, waiting to exhale...

\section{Dark Skin}

I touched the black crow lips as black as my skin is dark I am the black African princess respected by black men as I am a black strong Nubian goddess who has been through hell in my black skin my black race has retired many disguises of invisible black words I a black celestial queen invisible to the clouds and the stars who wears a mask of black pride of black culture of black existence I speak of black hope every tear I have shed into the black sea of black melted ice hidden the signs of black hope enchanted by my black spirit black spirit that soars through light through the heavenly winds of night I yearn beautiful experiences of energy the speed of light black life through the age of birth I kissed life into the black souls of fate that speak in many tongues with the promise between our black souls would remain as a sign of black hope I am the black womb the black poem the black child the black female who asks to exist within this black mask because my dark skin needs to breath

\section{For the colored girl}

I am a black sister a black soul sister a black right on time sister a black give me five sister a black no fooling sister a black I just got to have it sister a black you better not play me sister a black try me sister a black give me a dime sister a black scared of that sister a black is you for real sister a black you better watch your back sister a black show you right sister a black I'm all that sister a black 24/7 sister a black I'm so good sister a black slap me because I am too good sister a black gotcha sister a black penny for your thought sister a black you so cool sister a black bad dressing sister a black cool cat sister a black you better respect sister a black sister with class sister a black representing sister a black you better recognize sister a black no playing sister a beautiful black motivated educated free spoken sister a black sister who don't play. 


\section{Gran-ma's cooking}

She milked the cow

She churned the butter

She squeezed the juice

She sifted the flour

She kneaded the dough

She shed the peas

She snapped the beans

She shucked corn

She washed the greens

She plucked the hen

She scaled the fish

She canned fresh fruit

She fried fish in a skillet

She stir-fried cream corn

She steamed the cabbage

Cooked hot-water corn bread

Fried green tomatoes

With skillet spaghetti to burn

She made home-made syrup

Fresh butter-milk biscuits

Fried salmon crockets deer and rabbit

And boiled freshly-picked brown eggs

She made home-made turnovers

Picked with fresh apples and peaches from the garden

Four-layered jelly coconut or caramel cake from scratch

Bread pudding blackberry cobbler or peach pie

My gran-ma was the best cook I've ever had

She put her cat in her food

She kept our bellies full

And Gran-ma's kitchen was always clean

\section{Grandma's Hands}

Her spewed

Weak

Tired

Poor

Hands

Stitched embroidered crocheted

Wary

Prudent

Nuzzled

Yarn string thread

Carefully

Weaved

Knitted

Sewn 
Reattached

Through loops

Patterns

Shapes

Scraps of cloth

Pieced

Matched

Sorted

Through secrets

Customs

Heritage

A quilt

A blanket

An afghan

Her sacred hands

Emanated a cultural tradition

\section{Where I Stand}

I, am woman

I hold universal thought

My hands grasp life

Palms together

Releasing truth

To be told

In many tongues

I celebrate revelation over irony

It is how I stand my ground

Death has passed me

I am invisible

I am a child of God

I feel solace

With reality

I explore

Controversy

I celebrate purpose

With the courage to forgive

I am full of life

I live peacefully

\section{Dance}

I, feel movement

Passionate movement. 
I leap with emotion

Expelling with conviction.

I, surrender expression

Of agility and grace.

I, am a beam of light

Flowing through gravity.

I am the universe in motion.

I am the expression of response.

\section{A Poets Craft}

A poet speaks of wisdom

From the mad voice within.

Words that burn each page with rage

Conversing feeling through metaphors.

A poet's passionate desire conveys a lust

Of having her voice heard.

A poet may choose to define hidden meaning

To demand reasons to be understood.

\section{Dance}

I am kinesthetic ability of action alive, communicating, receiving I am the poised expression of proficient distance.

I am this dance of life soaring into a sky of surrender

I am this dance of life leaping oceans of love and grace.

I dance the distance between stoic formations

I dance arms legs hips beyond a sky of loneliness and aloneness.

1969

a city is free

fire blazes unfuraled

1969

the angry tired souls

a riot sprung

a protest launched

a last hope redeemed

red, grey colored sky

marked barron streets

hate, denial, betrayal

in West Las Vegas

a broken, separate, drought passage 


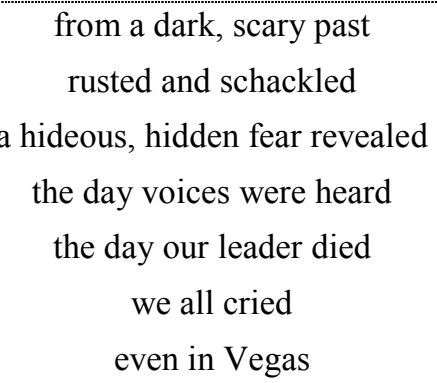

\section{Discussion}

It became a time when I wanted to reach an audience to feel the struggle of my race in this generation. This generation where blacks thought it is cool to go to jail. It is a generation where lot of boys and girls who get locked in prison. It is a generation of a large population of aids victims. It is a generation where single women have to raise a family alone. It is a generation of the poverty gap is large amongst blacks. It is a generation of high drop-out rates in school. It is a generation of girl prostitution. High rate of gays and lesbian women who live privately outside the church. I am reflective to our troubled youth that a black poor person can become an educated poet as an inspiration to young readers.

\section{Conclusion}

I like to read poetry and short fiction. The types of poems I like to read are from the Harlem Renaissance. My favorite poets are Nikki Giovanni, Maya Angelou and Langston Hughes. I also like to read other famous poets modern poem anthologies. I read poetry every week to study the poet's style and craft. My favorite poem by Nikki is Cotton Candy on a Rainy Day. My favorite poem by Angelou is Why the Caged Bird Sings. My favorite poem by Langston is America. I like Gwendolyn Brooks' poem Kitchenette. I also like Browning, Frost, Plath and Emily Dickenson. I find myself writing once a week. I pressure my thought process to think, read and to write poetry. Poetry is like therapy for me. I write about cultural issues reflected of my Las Vegas culture in how I relate to having mental illness. Some African American instructors consider my form of writing like Civil Rights poem. A Resolution is a poem written about the social conventions of African American struggle for cultural diversity. America is a poem written about the struggle for African Americans in our conquest to having equality. When I write I am happy for others to reflect on my ideas and relate to them in their own way. My short term goals is to express myself with clarity in my poems. My long term goal is to develop a quality poem to get my poems published. 